\title{
Two species of Rhabdochona (Nematoda: Rhabdochonidae) from the cyprinid fish Luciobarbus kersin (Heckel) in northern Iraq, including $R$. (Globochona) kurdistanensis sp. n.
}

\author{
František Moravec $^{1}$, Samir J. Bilal ${ }^{2}$ and Shamall M. A. Abdullah ${ }^{2}$ \\ ${ }^{1}$ Institute of Parasitology, Biology Centre of the Academy of Sciences of the Czech Republic, Branišovská 31, 37005 České \\ Budějovice, Czech Republic; \\ ${ }^{2}$ College of Education / Scientific Departments, University of Salahaddin, Erbil, Kurdistan Region, Iraq
}

\begin{abstract}
A new nematode species, Rhabdochona (Globochona) kurdistanensis sp. n. (Rhabdochonidae), is decribed based on specimens collected from the intestine of the barbel Luciobarbus kersin (Heckel) (Cyprinidae) in the Greater Zab (type locality) and the Lesser Zab Rivers, Tigris River basin, Kurdistan Region, northern Iraq. It is mainly characterized by a prostom with 8 anterior teeth, the presence of basal prostomal teeth, bifurcated deirids, length ratio of the muscular and glandular portions of oesophagus (1:14.4-17.8), conspicuously short left spicule (180-204 $\mu \mathrm{m})$, arrangement of genital papillae, nonfilamented eggs, and by having cuticular ornamentations on the tail tip ( 2 lateral denticular outgrowths in female and numerous fine spines in male). Description of a gravid female of Rhabdochona (Rhabdochona) sp. with 14 anterior prostomal teeth and filamented eggs, recorded from L. kersin of the Greater Zab River, is also provided. R. kurdistanensis sp. $\mathrm{n}$. is the fifth valid species of Rhabdochona Railliet, 1916 and the only representative of the subgenus Globochona Moravec, 1972 recorded from Iraq.
\end{abstract}

Keywords: Parasitic nematode, Rhabdochona, freshwater fish, Luciobarbus, Iraq

At present the nematode genus Rhabdochona Railliet, 1916 includes 94 valid species parasitizing freshwater fishes in all main zoogeographical regions (Moravec and Yooyen 2011). According to Moravec et al. (2009), the following four valid species of this genus have so far been recorded from Iraq: Rhabdochona denudata (Dujardin, 1845), R. hellichi (Šrámek, 1901), R. similis Moravec, Ali et Abul-Eis, 1991 and $R$. tigridis Rahemo, 1978 (see also Rahemo 1978, Rahemo and Kasim 1979, Ali et al. 1987, Moravec et al. 1991, Saraiva et al. 2007). However, an additional two species, $R$. chodukini Osmanov, 1957 and $R$. gnedini Skryabin, 1946 (correctly 1948 - see Moravec et al. 2008), were reported by Bilal and Abdullah (2010) from fishes of northern Iraq, but these identifications may be questioned (see below). Except for $R$. chodukini, all the above-mentioned species belong to the nominotypical subgenus Rhabdochona Railliet, 1916 according to the classification system proposed by Moravec (1972). In addition, Moravec et al. (2009) reported Rhabdochona sp. fourth-stage larvae from cyprinids Barbus barbulus Heckel, Luciobarbus kersin (Heckel) and Cyprinion macrostomum Heckel from the Tigris River basin, which are representatives of the subgenus Globochona Moravec, 1972. Also R. chodukini belongs to this subgenus (Moravec 1975).
Recently Al-Taee and Zangana (2011) established an allegedly new species of Rhabdochona, R. khazirensis Al-Taee et Zangana, 2011, based on one male and two female specimens found in the intestine of Alburnus mossulensis Heckel (reported under the synonym A. capito) (Cyprinidae) of the Khazir River near Mosul, northern Iraq. Unfortunately, its description is poor and seems to be confused (e.g., the male is reported to possess three lips and a short oesophagus with caeca!) and no specific, taxonomically important features are provided; the accompanying poor-quality photos only support a view that not all specimens belonged in fact to Rhabdochona. Since the species description is not accompanied by a statement how to differentiate the taxon (see International Code of Zoological Nomenclature, Article 13.1.1), the name $R$. khazirensis is not available. Further studies are necessary to determine the species appurtenance of Rhabdochona specimens from $A$. mossulensis in Iraq.

During recent investigations of some freshwater fishes in Kurdistan Region, northern Iraq, adult nematodes evidently conspecific with Rhabdochona (Globochona) sp. larvae previously reported by Moravec et al. (2009) from the same river drainage system were recovered from the intestine of Luciobarbus kersin. A detailed study of these nematodes using the light and scanning electron 
microscopy has shown that they represent a new species. Its description is presented herein. In addition, a single gravid female specimen of Rhabdochona (Rhabdochona) sp. was recorded from the same host species (L. kersin) in the same locality as the above-mentioned new species and data on its morphology are also provided.

Luciobarbus kersin is a subtropical benthopelagic freshwater fish native in the Tigris River basin, distributed in Iran, Iraq and Turkey (Froese and Pauly 2011).

\section{MATERIALS AND METHODS}

During occasional examinations of cyprinid fishes from the Lesser Zab River at the town of Alton Kupri and the Greater Zab River at the town of Gwer (tributaries of the Tigris River) near the City of Erbil, Kurdistan Region, northern Iraq, carried out in June and July of 2011, Rhabdochona specimens $(\mathrm{n}=78)$ were collected from the barbel Luciobarbus kersin; also specimens of Procamallanus sp. (only females) were present in L. kersin from the Greater Zab River. Nematodes collected from the intestine were fixed and stored in $70 \%$ ethanol. For light microscopical examination (LM), nematodes were cleared with glycerine. Drawings were made with the aid of a Zeiss microscope drawing attachment. Specimens used for scanning electron microscopy (SEM) were first transferred to $4 \%$ formaldehyde solution; later they were postfixed in $1 \%$ osmium tetroxide (in phosphate buffer), dehydrated through a graded acetone series, criticalpoint-dried and sputter-coated with gold; they were examined using a JEOL JSM-7401F scanning electron microscope at an accelerating voltage of $4 \mathrm{kV}$ GB low. All measurements are in micrometres unless otherwise indicated. Fish names follow FishBase (Froese and Pauly 2011).

\section{RESULTS}

Family Rhabdochonidae Travassos, Artigas et Pereira, 1928

\section{Rhabdochona (Globochona) kurdistanensis sp. n.}

Figs. 1, 2

Description: Medium sized nematodes with finely transversely striated cuticle (Fig. 2D). Lateral alae absent. Mouth oval to roughly hexagonal (Figs. 1E, 2A,B). Four small submedian cephalic papillae and two lateral amphids present (Figs. 1E, 2A,B). Prostom funnel-shaped, thick-walled, with distinct basal teeth (Fig. 1C,D); anterior teeth 8 in number, 2 dorsal, 2 ventral and 4 lateral (2 on each side) (Figs. 1E, 2A,B). Deirids small, bifurcate, situated at level of posterior half of vestibule (Figs. 1B,C, $2 \mathrm{C})$. Excretory pore short distance posterior to nerve ring level (Fig. 1A,C). Tail of both sexes conical, its tail tip rounded, bearing cuticular outgrowths.

Male (3 specimens; measurements of holotype in parentheses): Body 10.85-12.28 (10.85) mm long, maximum width 177-218 (177). Vestibule including prostom 183-189 (183); prostom 24-27 (24) long and 21-24 (24) wide in lateral aspect. Muscular oesophagus 360-393 (360) long, width 39-42 (39); glandular oesophagus
5.24-6.12 (5.24) mm long, width 111-147 (111); length ratio of both parts of oesophagus 1:14.4-15.6 (1:14.5). Entire oesophagus and vestibule representing 51-57 (53)\% of body length. Nerve ring, excretory pore and deirids 246-261 (261), 394-422 (394) and 126-159 (159), respectively, from anterior extremity. Subventral preanal papillae occurred in following combinations: 9+9 and $10+10(9+9) ; 2$ (2) additional pairs of lateral preanal papillae situated between second and third and third and fourth pairs of subventral papillae (counting from cloacal opening). Postanal papillae: 6 pairs, of which 5 (5) pairs subventral and 1 (1) lateral (Figs. 1K, 2F,G). Precloacal ventral cuticular ornamentation (area rugosa) formed by numerous transverse bands with 3-4 transverse grooves, separated from each other by band-like fields bearing many low longitudinal, parallel ridges (Figs. 1H, 2H). Left spicule markedly short, 180-204 (204) long; its shaft 105-126 (126) long, representing 53-67 (62)\% of entire spicule length; distal tip slightly widened, moderately bifurcate (Fig. 1F). Right spicule boat-shaped, 66-90 (66) long, without dorsal barb at distal tip (Fig. 1G). Length ratio of spicules 1:2.00-3.09 (1:3.09). Tail 282-303 (282) long, with rounded tip bearing numerous minute spinelike protrusions (Fig. 1J,K).

Female (6 gravid specimens; measurements of allotype in parentheses): Body 12.28-18.99 (16.58) mm long, maximum width 190-326 (326). Vestibule including prostom 180-210 (210) long; prostom 27-30 (30) long and 24-27 (27) wide. Muscular oesophagus 360-448 (435) long, width 36-48 (39); glandular oesophagus 5.54-7.14 (6.80) $\mathrm{mm}$ long, width 120-163 (163); length ratio of both parts of oesophagus 1:15.2-17.8 (1:15.2). Entire oesophagus and vestibule representing 41-53 (45)\% of body length. Nerve ring, excretory pore and deirids 240-273 (273), 326-449 (449) and 135-141 (138), respectively, from anterior extremity. Tail conical, 198-249 (237) long, with rounded tip bearing two lateral denticulate outgrowths 3-6 (6) long and 9-15 (15) wide; each outgrowth distally subdivided into 4 horn-like projections (Fig. 2D,E). Vulva postequatorial, 7.93-12.50 (8.95) $\mathrm{mm}$ from anterior extremity, at 54-66 (54)\% of body length; vulval lips not elevated. Muscular vagina directed posteriorly from vulva. Eggs oval, thick-walled, embryonated, size 39-42 × 27-30 $(39-42 \times 27)$, with smooth surface (Fig. 1L); thickness of egg wall 3 (3).

Type host: Luciobarbus kersin (Heckel) (Cyprinidae, Cypriniformes) (body length $18-65 \mathrm{~cm}$ ).

Site of infection: Intestine.

Type locality: Greater Zab River $\left(36-37^{\circ} \mathrm{N}, 43-44^{\circ} \mathrm{E}\right)$ (Tigris River basin) at Gwer, about $44 \mathrm{~km}$ southwest of Erbil City, Kurdistan Region, northern Iraq (collected 13 June 2011).

Other locality: Lesser Zab River $\left(34-36^{\circ} \mathrm{N}, 43-46^{\circ} \mathrm{E}\right)$ (Tigris River basin) at Alton Kupri, $45 \mathrm{~km}$ south of Erbil City (collected 11 July 2011). 

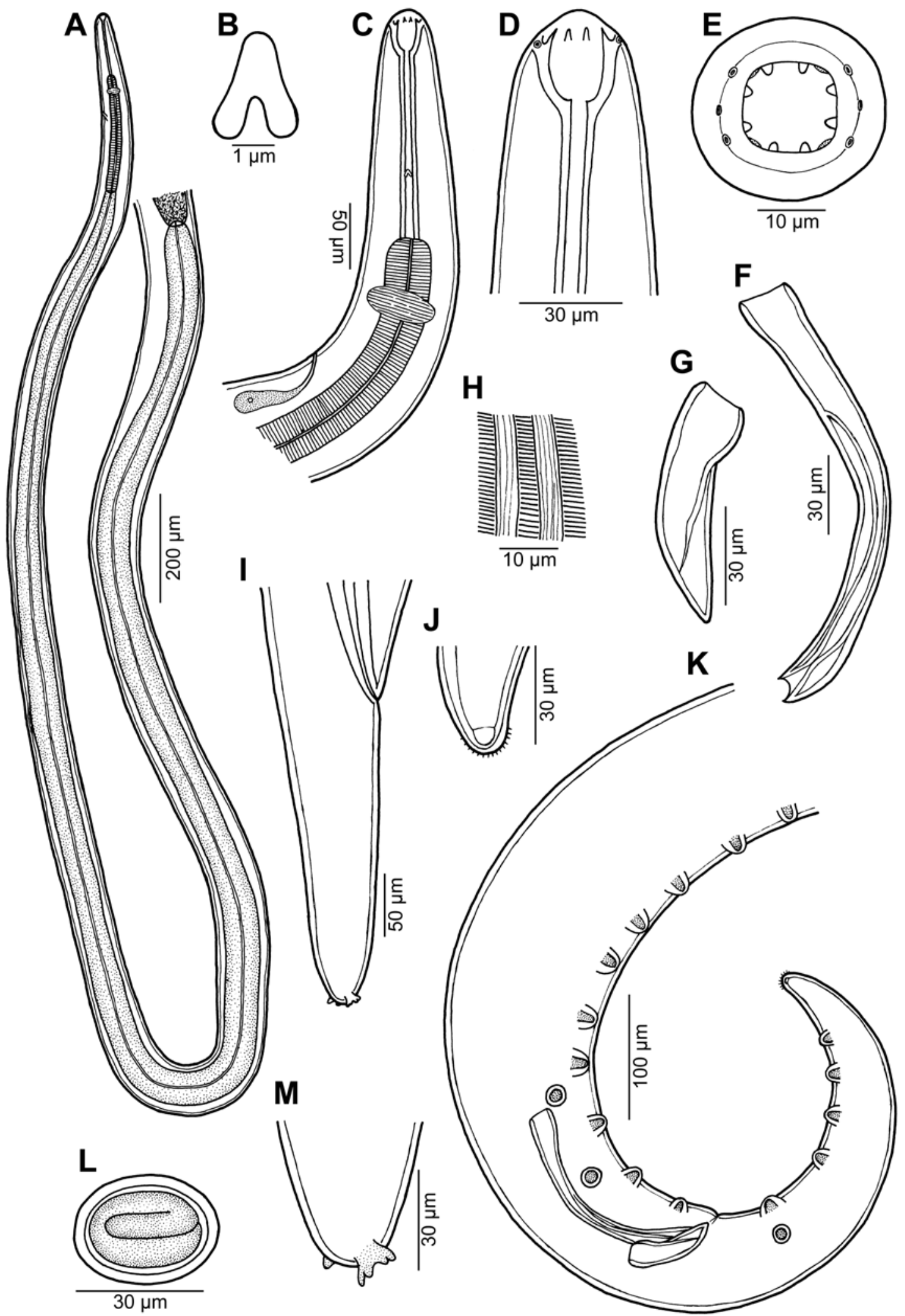

Fig. 1. Rhabdochona (Globochona) kurdistanensis sp. n. A-anterior part of male body, lateral view; B - deirid; C-anterior end of female, lateral view; D, E - cephalic end of female, lateral and apical views; $\mathbf{F}$ - left spicule; $\mathbf{G}$ - right spicule; $\mathbf{H}$ - ventral precloacal ornamentation; I - female tail, lateral view; $\mathbf{J}$ - tail tip of male, lateral view; $\mathbf{K}$ - posterior end of male, lateral view; $\mathbf{L}$ - egg; $\mathbf{M}$ - tail tip of female, lateral view. 

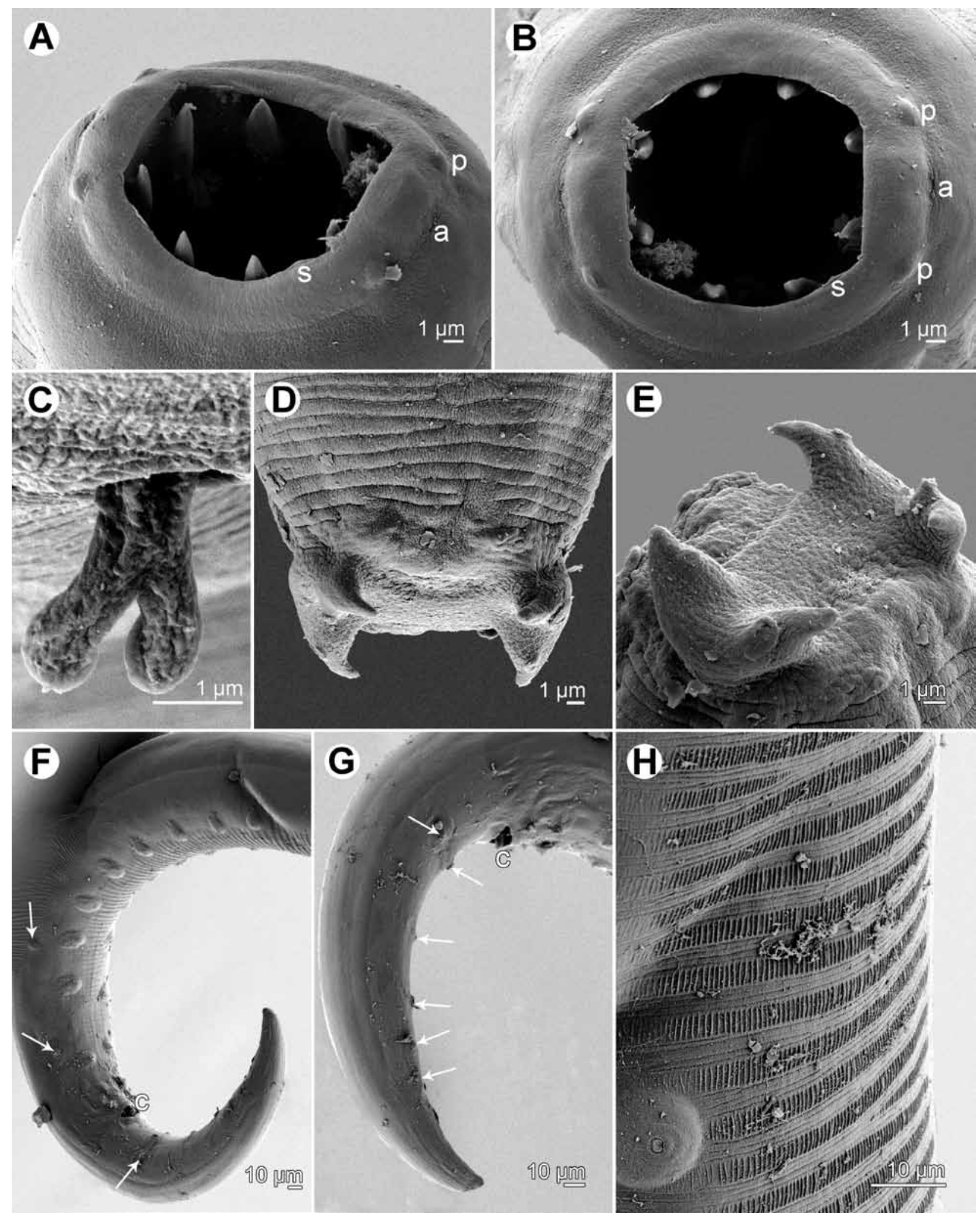

Fig. 2. Rhabdochona (Globochona) kurdistanensis sp. n., scanning electron micrographs. A, B - cephalic end, subdorsoventral and apical views, $\mathbf{C}$ - deirid, D, E - tail tip of female, dorsal and subapical views, $\mathbf{F}$ - posterior end of male, lateral view (arrows indicate lateral papillae), $\mathbf{G}$ - tail of male, lateral view (arrows indicate postanal papillae), $\mathbf{H}$ - ventral precloacal cuticular ornamentations of male, lateral view. Abbreviations: a - amphid; c - cloacal aperture; $\mathrm{p}$ - cephalic papilla; s - sublabium. 
Prevalence and intensity: Greater Zab River: 16 fish infected/43 fish examined; 3-9 nematodes per fish. Lesser Zab River: 11/48; 2-8 nematodes.

E t y mology: The specific name kurdistanensis relates to the region of its origin, i.e. Kurdistan, where specimens of the new species were found.

Dep osition of types: Holotype, allotype and paratypes in the Helminthological Collection of the Institute of Parasitology, Biology Centre of the Academy of Sciences of the Czech Republic, České Budějovice (Cat. No. N-981).

Remarks: Based on the number (8) of anterior prostomal teeth and the presence of caudal processes on the tip of the tail, the specimens of this species can be assigned to the subgenus Globochona, as diagnosed by Moravec (1975). Only a few species of Rhabdochona (Globochona) are known from freshwater fishes in tropical and subtropical Asia and Africa (Moravec 1975, 2010, Boomker and Petter 1993, Wang et al. 1994, Moravec and Yooyen 2011). In having a markedly short left spicule, bifurcate deirids and cuticular outgrowths on the tail tip of both sexes, $R$. (G.) kurdistanensis sp. n. is similar only to $R$. (G.) equispiculata Moravec et Scholz, 1991 from Hampala spp. in Laos and $R$. (G.) thaiensis Moravec et Yooyen, 2011 from Mystacoleucus marginatus (Valencienes) in Thailand. However, in contrast to the new species, both spicules of $R$. (G.) equispiculata are almost equally long (length ratio of spicules $1: 1.2$ vs. 1:2.0-3.1) and the tail tip of both sexes bears 3-4 slender cuticular spines, whereas $R$. (G.) thaiensis possesses two small claw-shaped ventral projections on the tail tip of both sexes (Moravec and Scholz 1991, Moravec and Yooyen 2011). In having a markedly short left spicule (161-174), bifurcate deirids and a length ratio of spicules about 1:2, also R. (G.) brevichona Wang, Yu et Wu, 1994, a parasite of Rectoris luxiensis Wu et Yao in China, resembles the new species. However, the male tail tip of $R$. (G.) brevichona is truncated, without any projections, whereas the tail tip of conspecific females is with a crown-like appendage provided with processes, and deirids are situated at the level of the posterior end of prostom (Wang et al. 1994) vs. at the level of the posterior part of vestibule.

There is also a certain similarity of the new species with $R$. (G.) chodukini Osmanov, 1957, the only species of this subgenus occurring in the Aral Sea basin (drainage systems of the Amu-Darya and Syr-Darya Rivers), the main hosts of which are barbels, Luciobarbus brachycephalus (Kessler) and L. capito (Güldenstädt) (see Osmanov 1957, Dzhalilov 1964, Moravec 1975). In his inadequate original description of $R$. chodukini, Osmanov (1957) mentioned the presence of a "ring-like formation with spines on its margin" on the tail tip of both sexes, but Moravec (1975), redescribing this species on specimens from L. brachycephalus and L. capito from Tajikistan, found the male tail tip rounded, without any projections (see also Vismanis et al. 1987). Consequently, $R$. chodukini differs from $R$. (G.) kurdistanensis mainly in having a markedly longer left spicule (352-420 vs. 180-204), simple deirids and the female tail tip provided with a crown consisting of many cuticular processes arranged in two circles, whereas the male tail tip is smooth, without any processes. Rasheed (1965) considered $R$. chodukini as possibly identical with $R$. sarana Karve et Naik, 1951, a species inadequately described solely from females found in Puntius sarana (Hamilton) in central India (Poona) (Karve and Naik 1951), but because the conspecific male remains unknown, Moravec (1975), Soota (1983) and Sood (1989) treated it as a separate species. Rhabdochona sarana can be distinguished from the new species by the structure of the female tail tip (reported as a stumpy projection with three blunt spines), a shorter glandular oesophagus in female (2.44-3.14 vs. 5.54-7.14 mm) and smaller eggs (27-35 × $17-20$ vs. $39-42 \times 27-30)$.

Rhabdochona (Rhabdochona) sp.

Figs. 3, 4

Female (1 gravid specimen): Body $14.67 \mathrm{~mm}$ long, maximum width 218. Mouth oval, with four small submedian sublabia. Four small cephalic papillae and pair of lateral amphids present (Figs. 3C, 4A,B). Vestibule including prostom 168 long. Prostom funnel-shaped, armed with 14 anterior teeth ( 3 dorsal, 3 ventral and 4 lateral on each side; lateral teeth forming pairs) and distinct basal teeth, 27 long and 21 wide (Figs. 3A-C, 4A,B). Muscular oesophagus 363 long, 48 wide; glandular oesophagus $5.30 \mathrm{~mm}$ long, 129 wide; length ratio of both parts of oesophagus 1:14.6. Entire oesophagus and vestibule representing $40 \%$ of body length. Nerve ring and excretory pore 240 and 340, respectively, from anterior extremity. Deirids small, bifurcate, 111 from anterior end of body (Figs. 3A,B,E, 4C). Tail conical, 216 long, with sharply pointed tip (Figs. 3D, 4D). Vulva postequatorial, $8.79 \mathrm{~mm}$ from anterior extremity, at $60 \%$ of body length. Muscular vagina directed posteriorly from vulva. Eggs small, oval, thick-walled, embryonated, size 30-33 × 21-24; thickness of egg wall 3; each pole of egg provided with minute swelling and one long tape-like filament of fibrous structure; filaments about 150 long and 18 wide (Fig. 3F).

Ho st: Luciobarbus kersin (Cyprinidae, Cypriniformes) (body length $18-65 \mathrm{~cm}$ ).

Site of infection: Intestine.

Locality: Greater Zab River $\left(36-37^{\circ} \mathrm{N}, 43-44^{\circ} \mathrm{E}\right.$ ) (Tigris River basin) at Gwer, about $44 \mathrm{~km}$ southwest of Erbil City, Kurdistan Region, northern Iraq (collected 13 June 2011).

Prevalence and intensity: 1 fish infected/43 fish examined; 3 nematodes.

Deposition of voucher specimen: Helminthological Collection of the Institute of Parasitology, Biology Centre of the Academy of Sciences of the Czech Republic, České Budějovice (Cat. No. N-983). 

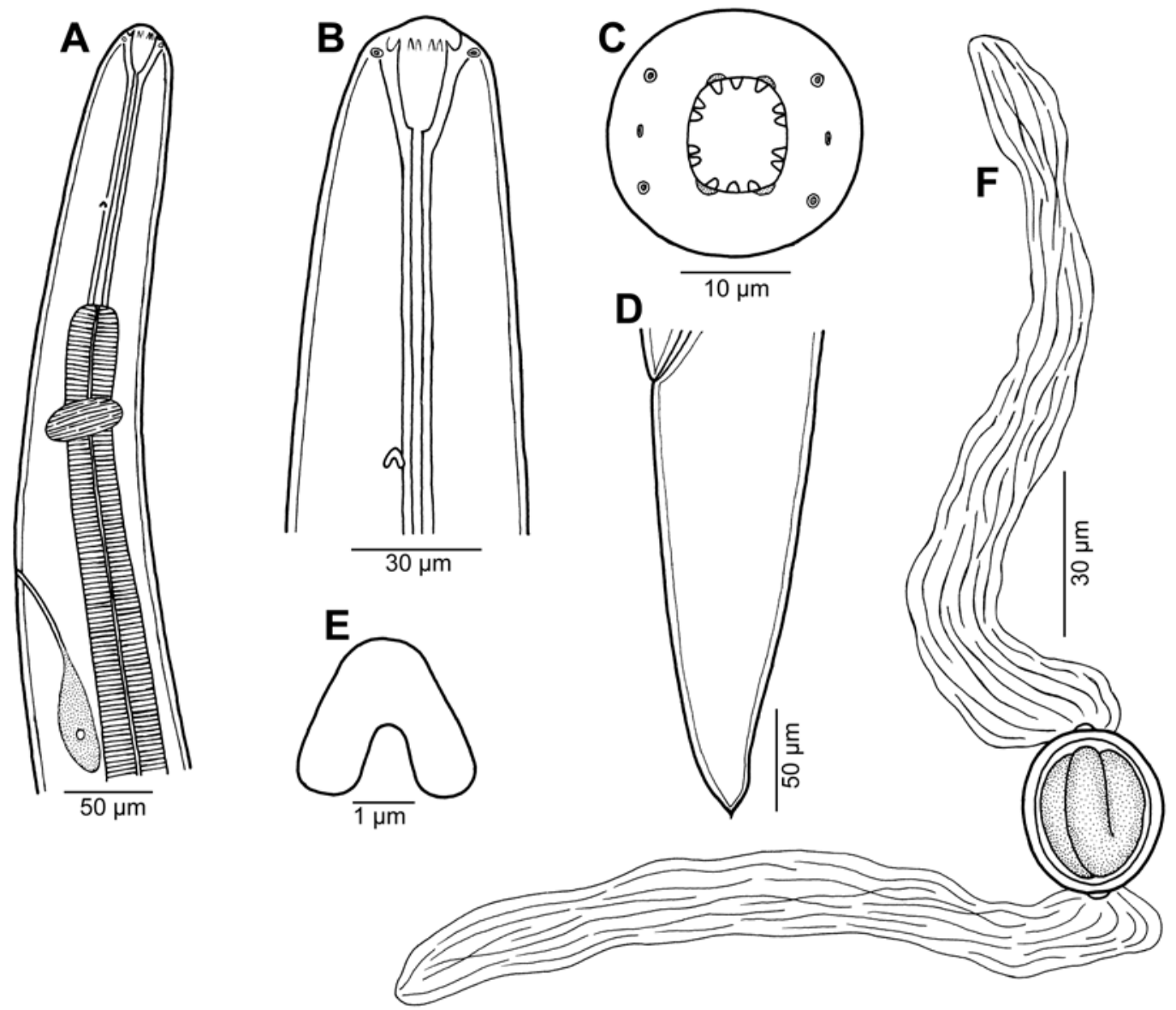

Fig. 3. Rhabdochona (Rhabdochona) sp. from Luciobarbus kersin, female. $\mathbf{A}$ - anterior end, lateral view; B, C - cephalic end, lateral and apical views; D - tail, lateral view; $\mathbf{E}$ - deirid; F - egg.

Remarks: The presence of 14 anterior prostomal teeth, filamented eggs and a sharply pointed female tail in the present specimen show that it belongs to the nominotypical subgenus Rhabdochona. Of the five species of this subgenus so far reported from Iraq (see above), four have filamented eggs: $R$. gnedini, $R$. hellichi, $R$. similis and $R$. tigridis. Of them, only $R$. gnedini and $R$. hellichi are typically parasites of barbels (Barbus spp.) and some cyprinids of related genera (Moravec 1975, Moravec et al. 2010), whereas the type host of $R$. similis is the catfish Glyptothorax sp. (Sisoridae, Siluriformes) (see Moravec et al. 1991) and the main hosts of R. tigridis are Capoeta spp. (Cyprinidae, Cypriniformes) (see Moravec et al. 2009, Bilal and Abdullah 2010).

\section{DISCUSSION}

Bilal and Abdullah (2010) reported large numbers of adult nematodes from Barbus barbulus and Luciobarbus kersin from the Bahdinan River (Tigris River basin), northern Iraq, identified as $R$. chodukini. However, this identification seems to be wrong, as visible from their description of these specimens, because some reported features, e.g., the presence of cuticular outgrowths on the male tail tip, do not agree with the morphology of
R. chodukini (see Moravec 1975). Despite some biometrical differences reported in the inadequate description of the specimens in question, it is highly probable that these nematodes belonged in fact to the new species $R$. kurdistanensis.

In Iraq, Moravec et al. (2009) reported Rhabdochona (Globochona) sp. fourth-stage larvae from the intestine of B. barbulus (prevalence $44 \%$, mean intensity 19 ) and L. kersin $(50 \%, 27)$ from the Kurdistan region (Bahdinan River, Tigris River basin), and from Cyprinion macrostomum (only 1 specimen found in 1 fish examined) from the Tigris River at Mosul. There is no doubt that these larvae were conspecific with $R$. (G.) kurdistanensis sp. n. The larvae reported by Moravec et al. (2009) from B. barbulus and L. kersin in Kurdistan were collected in November (unpublished), whereas the conspecific adults in L. kersin from the same region during June and July. This indicates that $R$. kurdistanensis may exhibit a pronounced seasonal cycle of maturation, when egg-producing females occur only in late spring and summer, as it was observed in some other Rhabdochona spp. in the temperate zone (Moravec 2010). Whereas both B. barbulus and L. kersin probably serve as definitive hosts of $R$. kurdistanensis, the finding of a single conspecific larva in C. macrostomum 


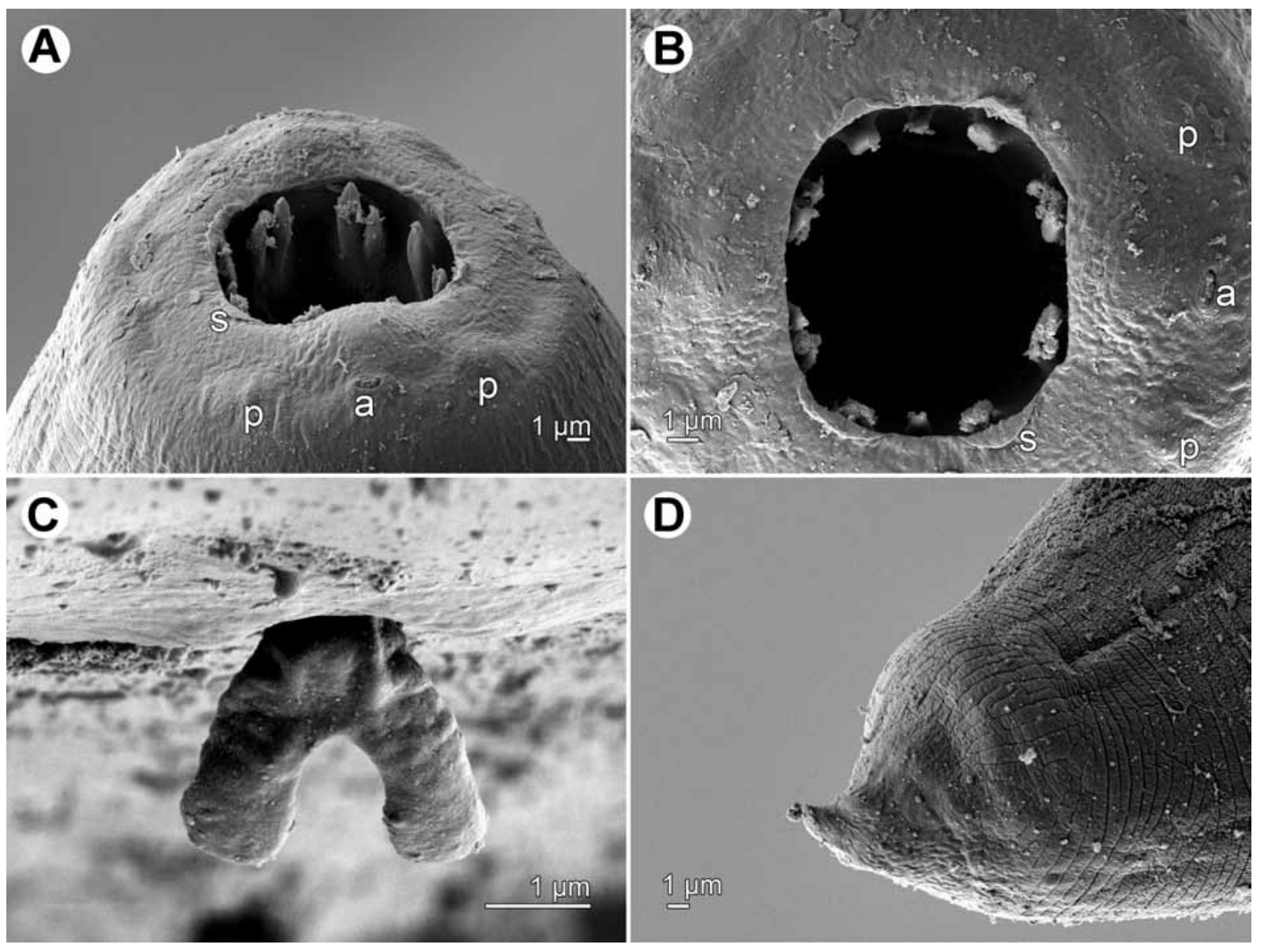

Fig. 4. Rhabdochona (Rhabdochona) sp. from Luciobarbus kersin, female. A, B - cephalic end, lateral and apical views; C - deirid; D - tip of tail. Abbreviations: a - amphid; $\mathrm{p}$ - cephalic papilla; $\mathrm{s}$ - sublabium.

suggests that this fish species is rather a facultative paratenic host for this nematode.

As compared to other Rhabdochona spp., R. kurdistanensis is remarkable for its unusually long oesophagus; this feature is also characteristic of the conspecific fourthstage larvae (Moravec et al. 2009). This species is also interesting in that its fourth-stage larvae have the same number (8) of anterior prostomal teeth as adults; in other congeneric species where fourth-stage larvae were studied, the number of these teeth is substantially smaller ( 6 or 8 ) than in adults (14 or 12) (Moravec 2010). The fourthstage larvae of $R$. kurdistanensis possess two lateral denticulate outgrowths at the tip of tail as conspecific adult females, but the number of horn-like projections on each outgrowth is $5-7$, in contrast to 4 in adult females.

A remarkable feature of $R$. (G.) kurdistanensis is also the structure of the male ventral precloacal ornamentation (area rugosa). In some Rhabdochona (Rhabdochona) spp. this male ventral cuticular ornamentation is formed, similarly to some cystidicolids, by several longitudinal ridges (e.g., in $R$. hospeti - see Moravec et al. 2010) or is completely missing. In contrast, the area rugosa of $R$. (G.) kurdistanensis is represented by many cuticular transverse bands with grooves, separated from each other by fields bearing numerous short longitudinal ridges (see Fig. $2 \mathrm{H}$ ). To date, this structure has never been reported for any Rhabdochona species (but the same structure has recently been observed in the African species $R$. (G.) congolensis Campana-Rouget, 1961; Moravec, unpublished).

Considering the four above-mentioned species of Rhabdochona with filamented eggs so far reported from Iraq, females of $R$. similis can be easily distinguished from that of Rhabdochona $(R$.) sp. of the present material by the large prostom $(69-78 \times 33-45$ vs. $27 \times 21)$ without basal teeth (vs. with basal teeth), simple deirids and a very long (561-573 vs. 216), conspicuously slender tail with the rounded tip bearing a minute terminal cuticular knob-like process. Females of $R$. tigridis differ markedly in having conspicuously large deirids situated at the level of the base of prostom, a much shorter glandular oesophagus (1.74-2.82 vs. 5.30$)$ and a slender tail.

The general morphology of the Rhabdochona $(R$.) sp. female from $L$. kersin is very similar to that of $R$. $(R$.) gnedini and $R$. (R.) hellichi, but also to that of the related species $R$. (R.) hospeti Thapar, 1950, a parasite of barbels in other regions, differing from the two first-named spe- 
cies in some features found in the male (Moravec 1975, Moravec et al. 2010). Since the conspecific male of the Rhabdochona $(R$.) sp. from L. kersin remains unknown, the specific identification of the present specimen is impossible.

Rhabdochona (Rhabdochona) hellichi (incorrectly reported as $R$. (R.) belichii) was reported from Iraq by Ali et al. (1987) from the cyprinid Luciobarbus xanthopterus Heckel (prevalence 11\%) and from two species of catfishes, Heteropneustes fossilis (Bloch) (8\%) and Mystus pelusius (Solander) (reported as M. halpensis) (57\%), of the Tigris River in Baghdad. However, the authors provided a poor description of their specimens and, moreover, the characteristic feature of this species, i.e., the widely bifurcate distal tip of the left spicule, is neither mentioned in the text nor is apparent from the accompanying photo (fig. $3 \mathrm{~b}$ ) of the male posterior end. Therefore, the belonging of these nematodes to $R$. hellichi may be questioned.

Recently, based on genetical and small morphological differences, Moravec et al. (2010) distinguished two subspecies within Rhabdochona hellichi: the nominotypical subspecies $R$. hellichi hellichi (Šrámek, 1901) parasitizing barbels (Barbus spp.) in Europe and $R$. hellichi turkestanica (Skryabin, 1917) parasitic mainly in species of Schizothorax and some related fish genera in Central and South Asia. In this connection, it is highly desirable to describe the male of Rhabdochona (Rhabdochona) nematodes parasitizing L. kersin in Iraq to identify them specifically and, if they actually belong to $R$. hellichi, to determine their subspecies based on morphological features and molecular data.
Regarding $R$. gnedini, this species has been, for the first time, reported from Iraq by Bilal and Abdullah (2010), who recorded numerous specimens from Capoeta damascina (Valenciennes) and Capoeta umbla (Heckel) from the Bahdinan River (Tigris River basin), northern Iraq. However, the presented description of these specimens is very incomplete and some taxonomically important features (e.g., the size and position of deirids) are not described; the left spicule is reported to be longer ( 830 860 ) than that in $R$. gnedini (at most 750 - see Moravec 1975); moreover, the definitive hosts of $R$. gnedini are principally barbels (Barbus spp. and fishes of related genera), whereas fishes of Capoeta spp. are mainly parasitized by some species of Rhabdochona noted for unusually large deirids, such as $R$. fortunatowi Dinnik, 1933, R. macrostoma Moravec et Mikailov, 1970 and R. tigridis Rahemo, 1978. A female specimen of the latter species (R. tigridis) (originally misidentified as $R$. fortunatowi, see Moravec et al. 2009) was reported by González-Solís et al. (1997) from Capoeta damascina in southwestern Iran. Therefore, the identification of Iraqi specimens as $R$. gnedini can be questioned and further detailed studies are necessary to determine whether or not these specimens belong to this species.

Acknowledgements. We thank Prof. Furhan T. Mhaisen for checking Iraqi rhabdochonid species. Thanks are also due to the staff of the Laboratory of Electron Microscopy, Institute of Parasitology, BC ASCR, České Budějovice, for their technical assistance, and to Blanka Škoríková of the same Institute, for her help with illustrations. This study was partly supported by the Czech Science Foundation (P505/12/G112) and the research project of the Institute of Parasitology, BC ASCR (Z60220518).

\section{REFERENCES}

Ali N.M., Salih N.E., Abdul-Ameer K.N. 1987: Parasitic fauna of some freshwater fishes from Tigris river, Baghdad, Iraq. IV. Nematoda. J. Biol. Sci. Res., Baghdad, 18: 35-45.

Al-Taee A.F., Zangana M.G. 2011: Detection of parasitic nematodes in some fresh water fishes in Khazir River in Ninevah governorate. Iraqi J. Vet. Sci. 25: 29-38. (In Arabic with English abstract.)

Bilal S.J., Abdullah S.M.A. 2010: Helminthic fauna of some cyprinid fishes from Bahdinar River, northern Iraq. J. Ass. Arab Univ. Base Appl. Sci. 8 (Year 2009): 17-29.

Boomker J., Petter A.J. 1993: Parasites of South African freshwater fish. III. Rhabdochona (Rhabdochona) versterae n. sp. (Nematoda: Rhabdochonidae) from the spot-tailed robber, $\mathrm{Al}$ estes imberi Peters, 1852. Onderstepoort J. Vet. Res. 60: 23-27.

DzhaliLov U.D. 1964: [Rhabdochonid materials (Rhabdochona Railliet, 1916) from fishes of the River Vakhsh and nearby lakes.] Izv. Akad. Nauk Tadjik. SSR, Otdel Biol. Nauk 1 (15): 109-117. (In Russian.)

Froese R., Pauly D. (Eds.) 2011: FishBase. World Wide Web electronic publication, www.fishbase.org, version 08/2011.

GonzÁlez-Solís D., Moravec F., Coad B.W. 1997: Some nematode parasites of fishes from southwestern Iran. Zool. Middle East 15: 113-119.
Karve J.N., NAiK G.G. 1951: Some parasitic nematodes of fishes - II. J. Univ. Bombay, Sect. B, Biol. Sci. 19: 1-37.

MoraveC F. 1972: General characterization of the nematode genus Rhabdochona with a revision of the South American species. Acta Soc. Zool. Bohemoslov. 36: 29-46.

MoraVeC F. 1975: Reconstruction of the nematode genus Rhabdochona Railliet, 1916 with a review of the species parasitic in fishes of Europe and Asia. Studie ČSAV No. 8, Academia, Prague, $104 \mathrm{pp}$.

Moravec F. 2010: Some aspects of the taxonomy, biology, possible evolution and biogeography of nematodes of the spirurine genus Rhabdochona Railliet, 1916 (Rhabdochonidae, Thelazioidea). Acta Parasitol. 55: 144-160.

Moravec F., Ali N.M., Abul-Eis E.S. 1991: Observations on two Rhabdochona species (Nematoda: Rhabdochonidae) from freshwater fishes in Iraq, including description of $R$. similis $\mathrm{sp}$. n. Folia Parasitol. 38: 235-243.

Moravec F., Santos M.D., Brasil-Sato M.C. 2008: Redescription of Cystidicoloides fischeri based on specimens from piranhas in Brazil, with erection of a new genus (Nematoda: Cystidicolidae). J. Parasitol. 94: 889-897.

Moravec F., Saraiva A., Abdullah S.M.A., Bilal S.J., RaHEMO Z.I.F. 2009: Two species of Rhabdochona Railliet, 1916 
(Nematoda: Rhabdochonidae) parasitising cyprinid fishes in Iraq, with a redescription of $R$. tigridis Rahemo, 1978 (emend.). Syst. Parasitol. 74: 125-135.

Moravec F., Scholz T. 1991: Observations on some nematodes parasitic in freshwater fishes in Laos. Folia Parasitol. 38: 163$178+$ Plts. I-VIII.

Moravec F., Scholz T., Ash A., Kar P.K. 2010: New data on the morphology and taxonomy of three species of Rhabdochona (Nematoda: Rhabdochonidae) parasitizing fishes in India. Folia Parasitol. 57: 295-306.

Moravec F., Yooyen T. 2011: Two new species of Rhabdochona (Nematoda: Rhabdochonidae) from freshwater fishes in Thailand. Folia Parasitol. 58: 224-232.

Osmanov S.O. 1957: [A new nematode from fishes of the AmuDarya.] Dokl. Akad. Nauk Uzbek. SSR 1: 63-65. (In Russian.)

RAнемо Z. 1978: Rhabdochona tigrae sp. n. (Nematoda, Rhabdochonidae) described from a freshwater fish, Varicorhinus trutta Heckel, from river Tigris, Iraq. Acta Parasitol. Pol. 25: 247-251.

Rahemo Z.I.F., Kasim M.H. 1979: Two new species of the Rhabdochona Railliet, 1916 (Rhabdochonidae) from a fresh water fish Cyprinion macrostomus [sic] Heckel, from Iraq. Jpn. J. Parasitol. 28: 371-376.
RASHEED S. 1965: A preliminary review of the genus Rhabdocho$n a$ Railliet, 1916 with description of a new and related genus. Acta Parasitol. Pol. 13: 407-424.

Saraiva A., Abdullah S.M.A., Bilal S.J. 2007: First record of Rhabdochona fortunatowi Dinnik, 1933 (Nematoda: Rhabdochonidae) in Iraq. Parassitologia 49 (Suppl.): 29.

Sood M.L. 1989: Fish nematodes from South Asia. Kalyani Publishers, New Delhi, 703 pp.

Sоота T.D. 1983: Studies on nematode parasites of Indian vertebrates I. Fishes. Records of the Zoological Survey of India, Occasional Paper No. 54. Zoological Survey of India, Calcutta, $352 \mathrm{pp}$.

Vismanis K.O., Lomakin V.V., Roytman V.D., Semenova M.K., TrofimenKo V.Y. 1987: [Nemathelminths - Nemathelminthes. In: O.N. Bauer (Ed.), Key to Parasites of Freshwater Fishes of the USSR Fauna]. Volume 3. Parasitic Metazoans, Part 2, Nauka, Leningrad, pp. 199-310. (In Russian.)

WANG G., YU Y., Wu H. 1994: Studies on two new species of Rhabdochona (parasitic nematodes) from Wuling Mountain Region. Acta Hydrobiol. Sin. 18: 280-286. (In Chinese with English abstract.) 